\title{
Brief Communication: Early season snowpack loss and implications for oversnow vehicle recreation travel planning
}

\author{
Benjamin J. Hatchett ${ }^{1,2}$ and Hilary G. Eisen $^{3}$ \\ ${ }^{1}$ Division of Atmospheric Sciences, Desert Research Institute, Reno, Nevada, 89512, USA \\ ${ }^{2}$ Western Regional Climate Center, Desert Research Institute, Reno, Nevada, 89512, USA \\ ${ }^{3}$ Winter Wildlands Alliance, Boise, Idaho, 83702, USA
}

Correspondence: Benjamin J. Hatchett (benjamin.hatchett@gmail.com)

Received: 29 August 2018 - Discussion started: 3 September 2018

Revised: 29 November 2018 - Accepted: 30 November 2018 - Published: 3 January 2019

\begin{abstract}
Oversnow vehicle recreation contributes to rural economies but requires a minimum snow depth to mitigate negative impacts on the environment. Daily snow water equivalent (SWE) observations from weather stations in the Lake Tahoe region (western USA) and a SWE reanalysis product are used to estimate the onset dates of SWE corresponding to $\sim 30 \mathrm{~cm}$ in snow depth $\left(\mathrm{SWE}_{\min }\right)$. Since 1985, median $\mathrm{SWE}_{\min }$ onset has shifted later by approximately 2 weeks. Potential proximal causes of delayed onset are investigated; rainfall is increasing during OctoberJanuary with dry days becoming warmer and more frequent. Adaptation strategies to address oversnow vehicle management challenges in recreation travel planning are explored.
\end{abstract}

\section{Introduction}

Ongoing and projected climate change is accelerating the warming of the cryosphere throughout Earth's mountain regions (Huss et al., 2017). Reductions in winter season snow, ice, and permafrost cover and volume primarily result from rising air temperatures (Brown and Mote, 2009) and shifts in precipitation from snow to rain (McCabe et al., 2018). These changes have cascading effects from mountains to lowlands with wide-ranging socioeconomic and ecologic impacts (Huss et al., 2017). In mountain regions of the United States, Europe, and Canada, winter recreation and tourism are central to economic activity. The economic benefits from winter recreation are projected to decline as a result of continued climate change that reduces season length and makes access to reliable snow more difficult (McBoyle et al., 2007; Scott et al., 2008; Wobus et al., 2017; Steiger et al., 2017).

Most winter tourism-based climate change impact studies have focused on ski-resort-related activity (Steiger et al., 2017), although research has begun to address how other recreation-based components of the winter economy may be affected (McBoyle et al., 2007; Scott et al., 2008; Tercek and Rodman, 2016; Wobus et al., 2017, Hagenstad et al. 2018). Skier visits are positively correlated to snowfall (Hagenstad et al., 2018) and we assume that such a correlation is consistent across winter recreation activities. Due to the dependence on natural snowfall and reduced adaptive capacity compared to the ski community, which can use cost-effective snowmaking to augment the natural snowpack, oversnow vehicle (OSV) recreation is highly vulnerable to climate variability and change (McBoyle et al., 2007; Scott et al., 2008). Climate change projections for Canada and the northeastern US under an aggressive greenhouse gas emissions scenario suggest that by the mid-21st century, OSV season lengths will be reduced by 50\%-100\% in most areas (McBoyle et al., 2007; Scott et al., 2008). A survey of the OSV community in Vermont found that reductions in the length of the winter season with sufficient snow coverage for OSV use were observed by $45 \%$ of respondents, with $74 \%$ of respondents decreasing their OSV use in response to low snow conditions (Perry et al., 2018). This survey also found that encounters with other recreationists, including OSV users, detracted from a high-quality recreation experience. The net effects of reduced season length, more congestion, and lower-quality experiences result in lower economic benefits from consumer surplus, or the amount a person is willing to pay over the 
(a)

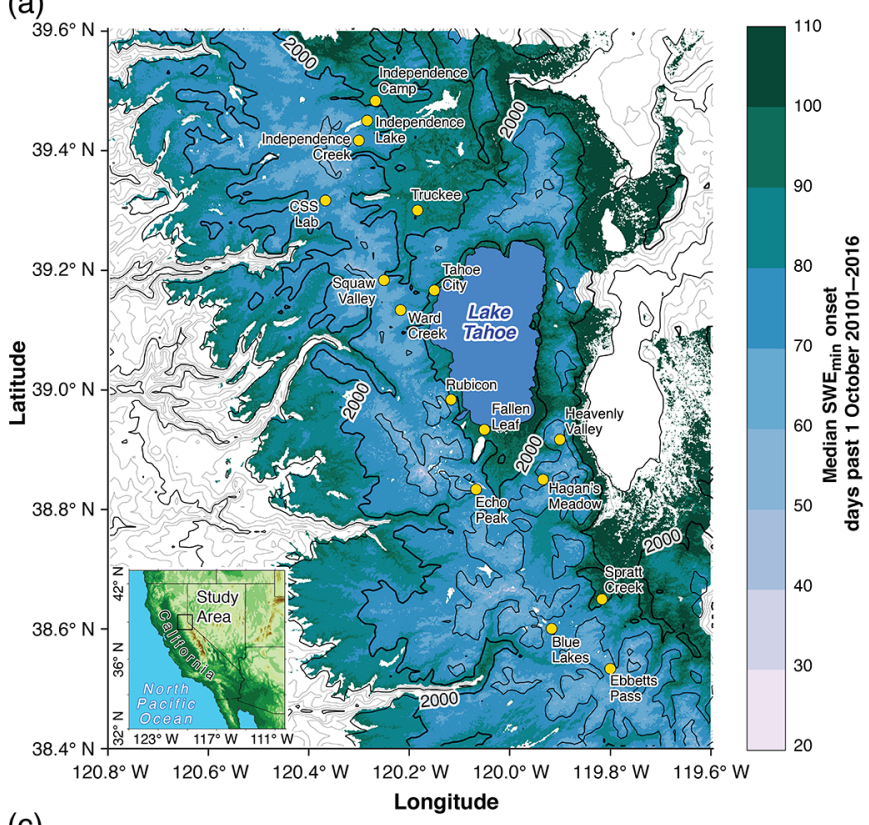

(c)

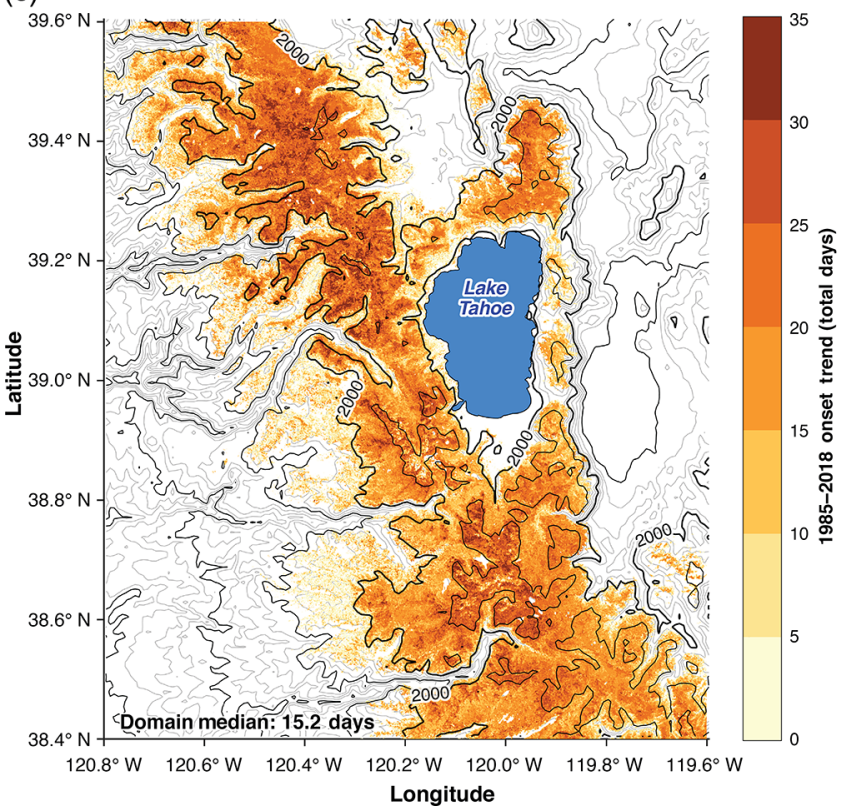

(b)

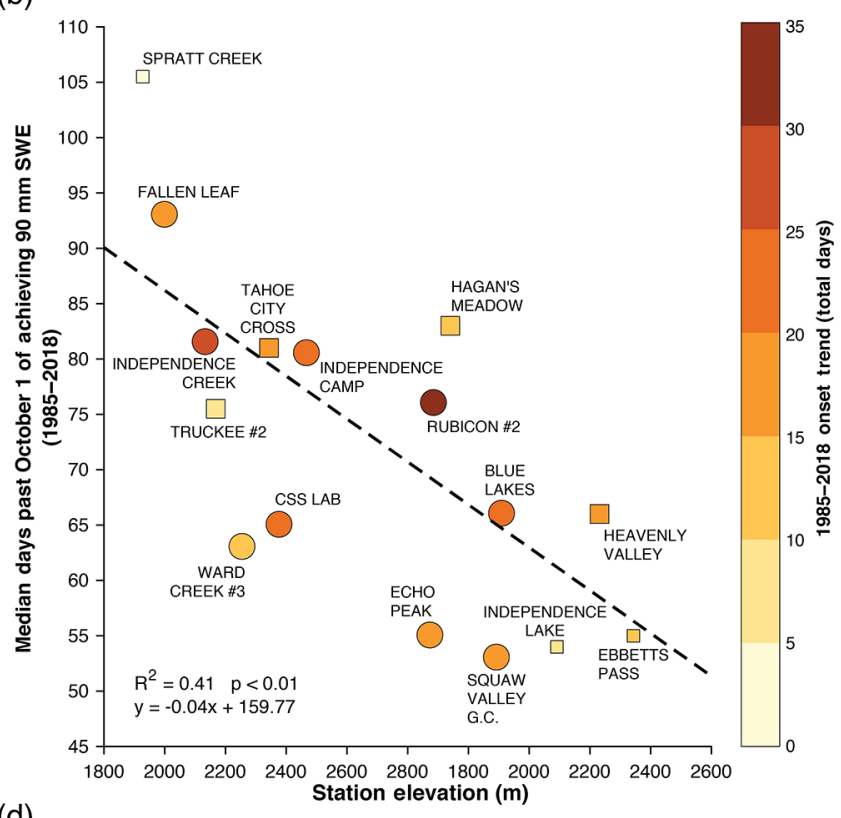

(d)

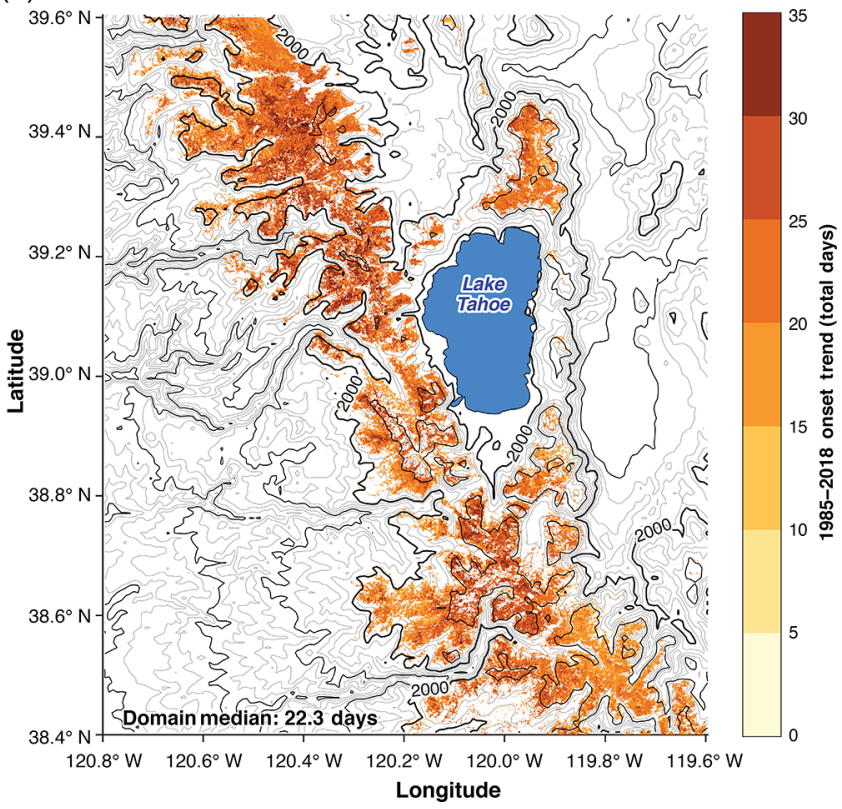

Figure 1. (a) Median 2001-2016 SWE $\min$ (days past 1 October) based on the SWE reanalysis product (Margulis et al., 2016) with SNOTEL stations shown as gold dots. The inset map shows the study area. (b) Timing of median $\mathrm{SWE}_{\min }$ (days past 1 October) by SNOTEL station elevation. Dots are colored by the trend (annual rate of snow depth timing change times 34 years). The dashed black line denotes the TheilSen linear fit. Large circles indicate significant trends $(p<0.1)$ for $\mathrm{SWE}_{\min }$, while large squares indicate a significant $(p<0.1)$ trend in $\mathrm{SWE}_{\min }$ was identified for a value of $\mathrm{SWE}_{\min }$ between 80 and $100 \mathrm{~mm}$. Small squares indicate no significant trend. (c) Spatially distributed Theil-Sen linear trends in $\mathrm{SWE}_{\min }$ over the period 1985-2016, calculated as the annual rate times the 32-year period. (d) As in (c) but showing only grid points with a statistically significant $(p<0.05)$ trend in onset date. In panels $(\mathbf{a})$, (c), and (d), the thin (thick) grey contour lines indicate elevations every $125 \mathrm{~m}(500 \mathrm{~m})$ while the thick black line indicates the $2000 \mathrm{~m}$ elevation contour (labeled). Grid points with more than three missing years were excluded from the analysis.

amount actually spent. For OSVs, consumer surplus is estimated to be approximately USD 61 person $^{-1}$ day $^{-1}$ (Hagenstad et al., 2018).
In the Lake Tahoe region of California (Fig. 1a), and many other rural mountain areas of the western US, OSV use is a regionally significant component of winter season recreation. Estimates of annual economic impact from OSV recreation 
in the United States range between USD 7 and 26 billion (Fassnacht et al., 2018). As a result, OSV recreation has an appreciable economic impact on rural counties within the northern Sierra Nevada, many of which have a greater dependence on tourism-related employment than elsewhere in California (United States Census, 2016).

The proximity of the Lake Tahoe region to large population centers creates demand for OSV recreation over a limited and ecologically sensitive area. In order to limit potential negative impacts on natural resources (e.g., Keddy et al., 1979) during OSV operation, a minimum snow depth must be present. Minimum snow depth restrictions have been proposed by several forests undergoing winter travel management planning across the Sierra Nevada. This restriction is usually proposed as a minimum depth of $30 \mathrm{~cm}$ of uncompacted snow (USFS, 2013). Few forests have such a requirement at this time, but several are currently engaging in the process of winter travel management planning in response to a 2015 US federal court ruling (Federal Register, 2015). The Eldorado National Forest in northern California (located in the southwestern quadrant of the study area) currently requires a minimum snow depth of approximately $30 \mathrm{~cm}$ for off-trail OSV use.

To our knowledge, no precise value of this minimum depth has been established through comprehensive studies quantifying OSV use and impacts or disturbance. Nonetheless, evidence indicates that OSV use can alter the landscape when a shallow snowpack is present. Keddy et al. (1979) observed that OSV use on very shallow snow (10-20 cm deep) doubled snow density and compressed underlying vegetation. When OSV use began under a deeper snowpack, less difference in snow density and hardness was observed compared to a control (no-OSV use) snowpack (Fassnacht et al., 2018). Further complicating the minimum depth requirement is the dependence of snow depth on the density of the snow, which varies seasonally and as a function of weather conditions that drive snowpack metamorphism processes (Sturm et al., 2010).

Resource managers tasked with day-to-day operations such as opening and closing OSV trailheads over large, diverse areas may not have the resources to visit trailheads to obtain snow depth and density measurements. Instead, they often rely on subjectively based qualitative assessments of what is deemed sufficient snow. Managers often do not set a specific OSV season, leaving it to user discretion to determine when OSV use is appropriate. This can potentially cause conflict with other uses during the start and end to the winter season and can allow opportunities for inadvertent damage to natural resources due to insufficient snow depth. Here, we estimate the median timing of achieving sufficient snow depths for OSV operation and their trends during the past 34 years using observations of snow water equivalent (SWE) and a reasonable assumption of snow density. We focus on the initial timing of sufficient snow depth since the greatest demands for OSV recreation and potential ecological impacts occur between early and middle winter. The proximal causes of the identified increasingly later onset of achieving a minimum SWE value are further investigated. Because the trend towards later onset is not expected to reverse under continued regional warming, we provide adaptation strategies to cope with diminishing early season snowpack resources that can be included in forest travel management plans. The techniques can be extended to other regions where OSV recreation is an important component of economic activity and where early winter snowpack losses may be impacting seasonal recreation.

\section{Data and methods}

The study area is the Lake Tahoe region of the western US, a coastal moderate-elevation snow-dominated mountain range (Fig. 1a). Daily maximum and minimum temperature, SWE, and precipitation were acquired for 16 SNOTEL stations from the Natural Resources Conservation Service (https://wcc.sc.egov.usda.gov/nwcc/tabget, last access: 1 June 2018). Daily, gridded estimates of SWE at $100 \mathrm{~m}$ horizontal resolution were provided by a satellite-era SWE reanalysis product (Margulis et al., 2015, 2016). The SWE reanalysis utilizes a Bayesian data assimilation framework to condition a priori snow model estimates with Landsat fractional snow-covered area images (Margulis et al., 2015). It verifies the posterior estimates against in situ daily snow pillow and monthly snow course data, which were found to compare favorably to previous studies (Margulis et al., 2016). The limitations of the remote-sensing approach include lower temporal frequency of Landsat passes (approximately every 16 days) and potential obscuration of the land surface by clouds and vegetation, which can reduce usable imagery. Challenges with the in situ verification data include representativeness or the discrepancies resulting from pointbased snow pillow versus transect-based snow course SWE measurements, undersampling of forested and sloped terrain, and the bias of sites towards the intermediate elevations of the Sierra Nevada $(50 \%$ of the stations are between 1500 and $2500 \mathrm{~m}$; Margulis et al., 2016). The period studied encompasses 1 October 1984 to 31 March 2018 (2016 for the SWE reanalysis), which corresponds to the winter seasons of 1985-2018.

No accepted value of a minimum snow depth exists for OSV operation. Anecdotal values used by managers vary between 15 and $45 \mathrm{~cm}$ depending on compaction (USFS, 2013), but these do not take into account variability in snow density. To provide a conservative and reasonable estimate of sufficient snow depth for what is assumed to be required for nonintrusive OSV operation, we specified $90 \mathrm{~mm}$ SWE (hereafter $\mathrm{SWE}_{\mathrm{min}}$ ) as the required minimum $\mathrm{SWE}$ corresponding to a minimum uncompacted depth of $30 \mathrm{~cm}$ for approval of OSV use. This value was obtained with Eq. (1):

$\mathrm{SWE}[\mathrm{mm}]=d[\mathrm{~mm}] \times \rho_{\mathrm{s}} / \rho_{\mathrm{W}}$, 
where $d$ is depth, $\rho_{\mathrm{S}}$ is the density of the snow, and $\rho_{\mathrm{w}}$ is the density of water. We assume that in a coastal snowpack with marginal compaction, $\rho_{\mathrm{s}}$ is typically $0.3 \mathrm{~g} \mathrm{~cm}^{-3}$ (Sturm et al., 2010). This value appears reasonable to approximate a depth of $30 \mathrm{~cm}$ for early season conditions and is consistent with values used by the USFS (2013). Our $\mathrm{SWE}_{\min }$ value is close to that of Patterson (2016) and Tercek and Rodman (2017), who both chose $100 \mathrm{~mm} \mathrm{SWE}$ as a threshold value for winter recreation in the Rocky Mountain National Park and Yellowstone National Park, respectively. We report the median timing of when each SNOTEL station and reanalysis grid point achieves $\mathrm{SWE}_{\min }$ and the annual timing as the median of the 16 SNOTEL stations.

To explore possible processes controlling the onset date of $\mathrm{SWE}_{\min }$, snow fractions $\left(S_{\mathrm{f}}\right)$ between 1 October and 31 January were calculated using the empirical hyperbolic tangent function formula developed by Dai (2008) with Sierra Nevada ecoregion parameter values estimated by Rajagopal and Harpold (2016). In contrast to Rajagopal and Harpold (2016), who used maximum temperature to estimate snow fraction, we selected average temperature because it gave a closer approximation to the median snow level ( $\sim 1750 \mathrm{~m})$ based upon independent estimates from observations (Hatchett et al., 2017). Dry days were days when less than the minimum measurable amount of precipitation $(2.54 \mathrm{~mm})$ was measured at SNOTEL stations. Mean minimum temperatures on dry days were calculated over the 16 stations for each year, as minimum temperature influences both snowpack dynamics and ecological processes (Oyler et al., 2015).

For all data, linear fits were estimated using a Theil-Sen slope and we report Spearman rank correlations. Statistical significance was tested using a modified Mann-Kendall test that accounts for serial correlation (see Hatchett et al., 2017, and references therein).

\section{Results and discussion}

\subsection{Timing of $\mathrm{SWE}_{\min }$}

Median timing of achieving $\mathrm{SWE}_{\min }$ ranged from early November to early January and was negatively correlated with elevation $\left(R^{2}=0.41, p<0.01\right.$; Fig. 1a and b). For the selected $\mathrm{SWE}_{\min }, 9$ of the 16 stations have significant $(p<0.1)$ trends towards later onset of $\mathrm{SWE}_{\min }$ (Fig. 1b). A total of 13 of the 16 stations demonstrated a significant $(p<0.1)$ trend when a value of $\mathrm{SWE}_{\min }$ between 80 and $100 \mathrm{~mm}$ was chosen (Fig. 1b). There was no relationship between trend in onset date and elevation, which suggests that regional weather variability is a first-order control on snowpack conditions. At the regional level, the median trend across all stations was 0.6 day $\mathrm{yr}^{-1}(p<0.001$; Fig. 2a). This equates to $\mathrm{SWE}_{\min }$ being achieved approximately 20 days later between the present day and the beginning of the record, although interannual variability still exists (Fig. 2a). Results from the SWE reanalysis product are broadly consistent with the station-based analysis, indicating timing of $\mathrm{SWE}_{\min }$ is largely a function of elevation (Fig. 1a). The median trend in the domain (approximately 15 days over the study period or 0.48 day $\mathrm{yr}^{-1}$ ) is close to the SNOTEL-based trend with the largest trends occurring above $2000 \mathrm{~m}$ (Fig. 1c). The median trend in the domain when only considering statistically significant grid points $(p<0.05)$ is approximately 21 days over the study period or 0.67 day yr$^{-1}$ (Fig. 1d). The consistency of the results between the independent SNOTEL data and the SWE reanalysis product supports the hypothesis that a delayed onset of $S W E_{\min }$ is occurring in the Lake Tahoe region. During years with later onset of $\mathrm{SWE}_{\min }$ (such as 1991, 2012, or 2014; Fig. 2a) most OSV users would likely opt out of recreating during much of the season due to potential mechanical damage to their vehicles. However, if sufficient snow existed above a certain elevation, inadvertent damage to the landscape could result when OSVs travel over shallow snowpacks in order to reach destinations with deeper snow. To ensure access to higher-elevation areas for OSV use during poor lower-elevation snowpack conditions, management plans could identify and implement corridors or rights-ofway that minimize landscape impacts while allowing access (Table 1).

\subsection{Possible drivers of timing changes of $\mathrm{SWE}_{\min }$}

The increasingly later onset of $\mathrm{SWE}_{\min }$ (Figs. 1c, 1d, and 2a) is consistent with an observed increase $\left(0.22\right.$ days $\mathrm{yr}^{-1}$, $p<0.0001)$ in the number of dry days during early winter (October-January; Fig. 2b). Minimum temperatures on dry days are also increasing $\left(0.098^{\circ} \mathrm{C} \mathrm{yr}^{-1}, p<0.0001\right)$. The observed decreasing trend towards reduced early season snow fraction $\left(S_{\mathrm{f}} ; 0.66 \% \mathrm{yr}^{-1}, p<0.0001\right.$; Fig. $\left.2 \mathrm{c}\right) \mathrm{im}-$ plies increasing numbers of warmer wet days, and a shift towards increased rainfall is likely contributing to later onset of $\mathrm{SWE}_{\min }$. The reduction in precipitation falling as snow is primarily driven by warming temperatures (McCabe et al., 2018), which may be controlled by regional atmospheric and oceanic circulations that favor higher-snow-level storms (Hatchett et al., 2017). The higher snow levels (and hence lower $S_{\mathrm{f}}$; Fig. 2a and c) reduce snowpack accumulation during precipitation events and can allow for snowpack loss due to turbulent heat fluxes and heat input by rain. The more frequent and warmer dry conditions create additional opportunities during which snowpack loss can occur via radiative and turbulent fluxes. The analysis of SNOTEL temperature is limited by inhomogeneities introduced by temperaturedependent sensor biases leading to overestimation of trends (Oyler et al., 2015). While overestimation is greatest at elevations above $3000 \mathrm{~m}$, additional assessments are needed to validate the robustness of the role of regional warming in reducing early season snowpack. 
Table 1. Adaptation strategies to address loss of early winter snowpack for OSV recreation.

\begin{tabular}{|c|c|c|}
\hline Adaptation measure & Benefit(s) & Challenge(s) \\
\hline $\begin{array}{l}\text { Requirement of minimum } \\
\text { snow depth off trail, but not } \\
\text { on roads/marked trails, or a } \\
\text { lower minimum snow depth on } \\
\text { roads/marked trails }\end{array}$ & $\begin{array}{l}\text { Allow OSV use even under extremely low- } \\
\text { snow conditions, limits resource damage in } \\
\text { wildlands; grooming could be utilized to } \\
\text { maximize snow depth on road }\end{array}$ & $\begin{array}{l}\text { Preventing users from going off trail un- } \\
\text { der low-snow conditions; enforcement, re- } \\
\text { sources required to obtain snow condition } \\
\text { information }\end{array}$ \\
\hline $\begin{array}{l}\text { Ensure high-elevation access via a } \\
\text { right-of-way }\end{array}$ & $\begin{array}{l}\text { During warmer/drier years, snow condi- } \\
\text { tions are likely to be better (deeper snow- } \\
\text { pack) at higher elevation }\end{array}$ & $\begin{array}{l}\text { User group conflicts; presence of wilder- } \\
\text { ness at high elevation; impacts on snow- } \\
\text { dependent wildlife species; demand; park- } \\
\text { ing }\end{array}$ \\
\hline Removal of blanket opening dates & $\begin{array}{l}\text { Prevents opening before } \mathrm{SWE}_{\min } \text { achieved } \\
\text { and will limit damage to landscape }\end{array}$ & $\begin{array}{l}\text { Resources required to obtain snow condi- } \\
\text { tion information }\end{array}$ \\
\hline $\begin{array}{l}\text { Identify corridors that col- } \\
\text { lect and retain more snow }\end{array}$ & $\begin{array}{l}\text { During otherwise poor snow conditions, } \\
\text { these areas may allow OSV recreation to } \\
\text { occur, particularly at lower-elevation areas }\end{array}$ & Need for data on these corridors \\
\hline $\begin{array}{l}\text { Improve durability of trailhead and } \\
\text { corridor trails }\end{array}$ & $\begin{array}{l}\text { Allows OSV recreation to occur when min- } \\
\text { imal snow exists, thereby reducing negative } \\
\text { impacts in high-use areas }\end{array}$ & $\begin{array}{l}\text { Need for specific quantification of how } \\
\text { to improve durability; potential permitting } \\
\text { problems }\end{array}$ \\
\hline $\begin{array}{l}\text { Trade-off: closure of low-eleva- } \\
\text { tion/sensitive habitat for improved } \\
\text { high-elevation access }\end{array}$ & $\begin{array}{l}\text { Eliminate chance of damaging landscapes } \\
\text { in low-elevation regions, increase in the } \\
\text { number of days per year that OSV recre- } \\
\text { ation can occur by enhanced high-elevation } \\
\text { access }\end{array}$ & $\begin{array}{l}\text { Need for collaboration between stakehold- } \\
\text { ers and user groups to identify areas where } \\
\text { compromise could occur; may be opposed } \\
\text { by those who must travel much further for } \\
\text { OSV use }\end{array}$ \\
\hline $\begin{array}{l}\text { Fee increases to enhance access } \\
\text { and offset impacts from higher de- } \\
\text { mand (i.e., restoration projects) }\end{array}$ & $\begin{array}{l}\text { Would provide for additional resources to } \\
\text { monitor trailhead conditions, im- } \\
\text { prove parking-bathrooms at trailheads, } \\
\text { fund restoration projects and creation of } \\
\text { low-snow OSV trails }\end{array}$ & $\begin{array}{l}\text { Fees are generally opposed by members of } \\
\text { the public }\end{array}$ \\
\hline Additional grooming & $\begin{array}{l}\text { Allows additional area for OSV use when } \\
\text { conditions are insufficient for off-trail use }\end{array}$ & $\begin{array}{l}\text { Costs for grooming equipment and person- } \\
\text { nel, many OSV users are primarily inter- } \\
\text { ested in off-trail use }\end{array}$ \\
\hline $\begin{array}{l}\text { Clear designation of non- } \\
\text { motorized areas (i.e., signage) }\end{array}$ & $\begin{array}{l}\text { Reduces user conflicts by improving } \\
\text { knowledge and awareness of areas open (or } \\
\text { closed) to OSV use }\end{array}$ & $\begin{array}{l}\text { Costs related to enforcement as well as in- } \\
\text { stallation and upkeep of signage }\end{array}$ \\
\hline
\end{tabular}

\subsection{Implications for regional winter travel management planning}

Due to its moderate elevation, the Lake Tahoe region is susceptible to climate-change-induced warming (Walton et al., 2017). Our results provide another metric (later onset date of $\mathrm{SWE}_{\min }$ ) that is consistent with observations of ongoing changes in the Sierra Nevada cryosphere, including rising winter snow levels (Hatchett et al., 2017) and snowpack declines (Mote et al., 2018). Climate model projections for California support the continuation of these trends, with a drying and warming of the fall season (Swain et al., 2018) and an increased frequency of dry days (Polade et al., 2015). Projected snow-covered area declines are estimated to be the greatest during the beginning and end of the snow season (Walton et al., 2017). As a result, forest travel management plans should include adaptation strategies (Table 1) that can help managers and recreationists cope with the increasing chances of a later opening date for OSV use but also provide flexibil- ity in the event of an early, snowier-than-normal start to the winter. Flexible strategies developed by diverse stakeholder groups through public discourse are encouraged, as the continued reduction of area available for motorized and nonmotorized users will lead to increasingly frequent use conflicts if not addressed. More frequent use conflicts, particularly at trailheads or in congested areas, may lead to decreases in high-quality experiences (Perry et al., 2018) and contribute to declines in OSV or other forms of recreational usage that reduce positive economic impacts (Hagenstad et al., 2018).

Developing a suite of adaptive management strategies is essential if land managers are to meet legal obligations to manage OSV recreation in a manner that minimizes impacts to natural resources, wildlife, and conflict among uses (Federal Register, 2015). As snow seasons become more variable and less dependable overall, it will be necessary to utilize several complementary management strategies if land managers want to continue to provide high-quality opportunities for all forms of winter recreation. For example, setting 

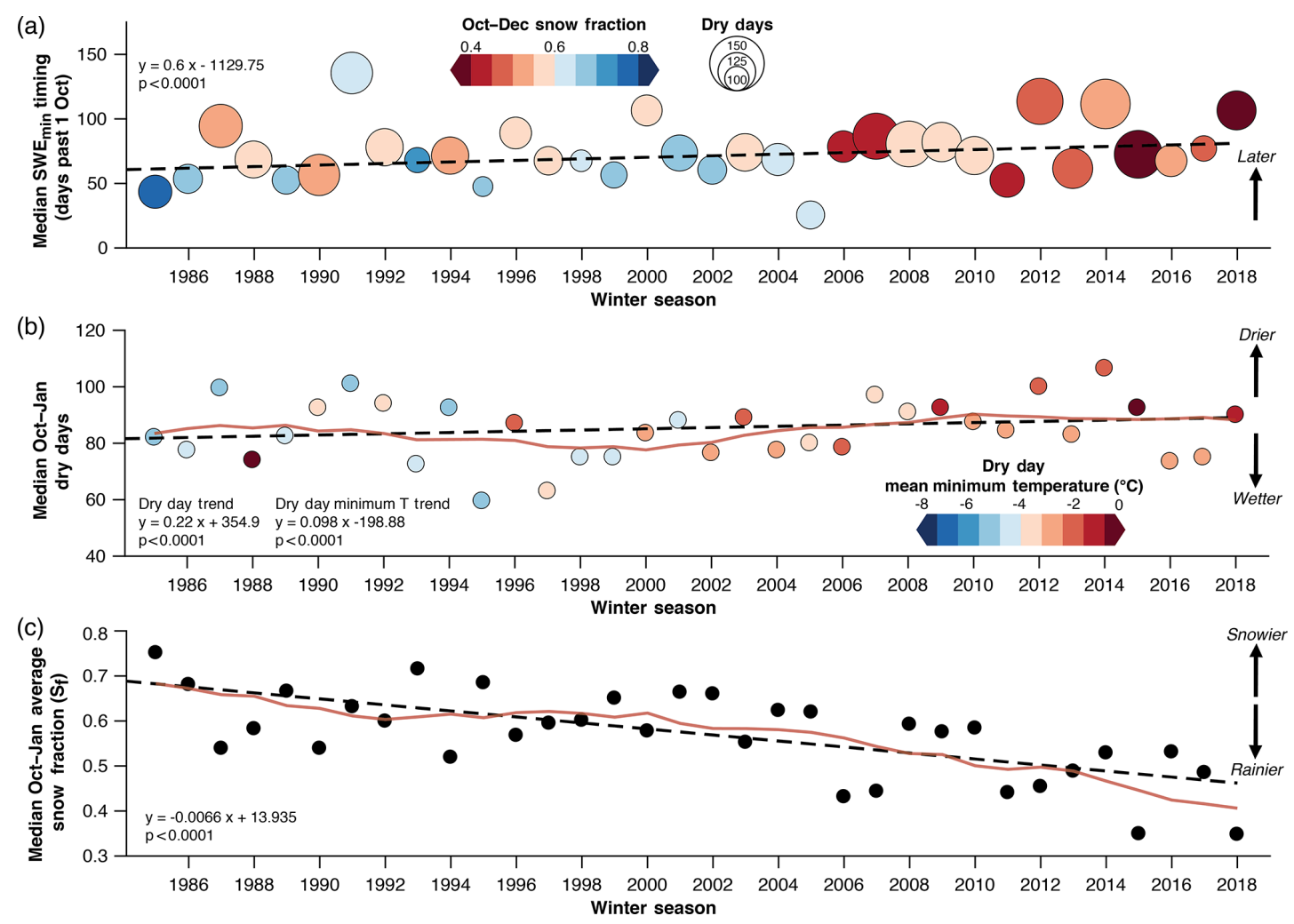

Figure 2. (a) Annual median timing of $\mathrm{SWE}_{\min }$ (days past 1 October) with dots colored by median October-January average snow fraction and sized according to the median number of October-January dry days. (b) Median early season (1 October-31 January) dry days with dots colored by average October-January minimum temperature. (c) As in (b) but for median snow fraction averaged over the 16 stations. In all figures, the dashed lines demonstrate Theil-Sen linear fits and red lines $(\mathbf{b}, \mathbf{c})$ show the 5-year running mean.

season dates that encompass the general times of the year when OSV use is appropriate, paired with a minimum SWE (or snow depth, depending on data availability), and allowing for OSV use on certain routes with a lower snowpack to provide access to higher-elevation areas may help to extend the OSV season. Likewise, it may be necessary to relocate winter trailheads to higher elevations as areas with consistent snowpack become shifted upwards in elevation. As the strategies in Table 1 show, however, there are trade-offs with any strategy and OSV recreation is not the sole use of public lands in winter. Managing OSV recreation must occur in concert with managing other forms of winter recreation and protecting wildlife and natural resources (Federal Register, 2015). There is no one-size-fits-all strategy that will work for every national forest. It is essential that land managers work with public and agency stakeholders to craft locally appropriate and equitable adaptation measures, taking into account potential impacts on and conflicts with other recreation uses, wildlife, natural resources, and other land management goals. It may also be necessary to accept that in the future, OSV and other forms of winter recreation (e.g., backcountry skiing and snowshoeing) will not be supported across all of the areas where it historically occurred. Winter travel planning is thus an excellent opportunity for land managers, par- ticularly the US Forest Service, to proactively address OSV management and consider how climate change is affecting OSV activities in national forests in order to maintain the opportunity for this form of winter recreation and its positive economic impact.

\section{Concluding remarks}

Using snow water equivalent and a density assumption as a proxy for depth, we have presented a pilot study aimed at a better understanding of when the Lake Tahoe region attains sufficient snowpack depth to allow safe oversnow vehicle (OSV) usage. A station-based analysis of 16 remote weather stations in the region and a spatially distributed SWE reanalysis product indicated that the median timing of achieving sufficient depth varies with elevation from early November to late December. The median timing of sufficient depth has increased by approximately 2 weeks during the past 3 decades with significant changes on the order of 3 weeks. The proximal causes for this shift towards later onset appear to be due to both a shift from snowfall to rainfall and increases in dry day frequency and temperature during the early winter season. However, further research is needed to estimate 
specific contributions from each cause and constrain the role of surface-albedo and/or humidity feedbacks at various elevations throughout the region (Patterson, 2016; Walton et al., 2017).

A primary limitation of our study is the lack of an established snow depth to avoid negative impacts of OSV operation as a function of land cover type and snow density. The work of Fassnacht et al. (2018) represents an important advance towards achieving this value, which can be used to guide winter travel management planning, although the US Forest Service has begun to recommend a snow depth (USFS, 2013). Additional studies on achieving regionally relevant minimum snow depths and better quantification of economic and ecological impacts from reduced-snow-cover area and duration will guide more robust travel management plans in national forests. They can also help prioritize pragmatic adaptation strategies for specific regions. Given the economic impact of OSV recreation and likely reduction in land available for OSV or other human-powered recreation uses (McBoyle et al., 2007; Scott et al., 2008; Tercek and Rodman, 2016; Hagenstad et al., 2018), combined with increasing numbers of winter recreation participants (Fassnacht et al., 2018), achieving winter travel management plans that are adaptive to varying snowpack conditions while minimizing user conflicts will be a key step towards sustainable mountain recreation.

Code and data availability. Data from the SNOTEL network are available via the US Natural Resources and Conservation Service website: https://wcc.sc.egov.usda.gov/nwcc/tabget (United States Department of Agriculture Natural Resources Conservation Service, 2018). The gridded snow water equivalent reanalysis products are available at https://ucla.app.box.com/v/SWE-REANALYSIS (last access: 15 June 2018).

Author contributions. BJH and HGE conceived and designed the study, interpreted the results, and wrote the paper. BJH acquired data and performed the analysis.

Competing interests. Hilary G. Eisen is employed by the Winter Wildlands Alliance (WWA). Benjamin J. Hatchett has consulted for the WWA.

Acknowledgements. The project described in this publication was supported by grant number G14AP0076 from the US Geological Survey (USGS). Its contents are solely the responsibility of the authors and do not necessarily represent the official views of the USGS. This paper was submitted for publication with the understanding that the US Government is authorized to reproduce and distribute reprints for governmental purposes. We greatly appreciate the constructive review comments by Glenn Patterson, Daniel Scott, and Editor Ross Brown that helped us improve the quality of this paper.

Edited by: Ross Brown

Reviewed by: Glenn Patterson and Daniel Scott

\section{References}

Brown, R. D. and Mote, P. W.: The Response of Northern Hemisphere Snow Cover to a Changing Climate, J. Climate, 22, 2124 2145, https://doi.org/10.1175/2008JCLI2665.1, 2009.

Dai, A.: Temperature and pressure dependence of the rain-snow phase transition over land and ocean, Geophys. Res. Lett., 35, L12802, https://doi.org/10.1029/2008GL033295, 2008.

Fassnacht, S. R., Heath, J. T., Venable, N. B. H., and Elder, K. J.: Snowmobile impacts on snowpack physical and mechanical properties, The Cryosphere, 12, 1121-1135, https://doi.org/10.5194/tc-12-1121-2018, 2018.

Federal Register: Use By Over-Snow Vehicles (Travel Management Rule) available at: https://www. federalregister.gov/documents/2015/01/28/2015-01573/ use-by-over-snow-vehicles-travel-management-rule (last access: 2 July 2018), 2015.

Hagenstad, M., Burakowski, E. A., and Hill, R. Economic contributions of winter sports in a changing climate, available at: https://scholars.unh.edu/cgi/viewcontent.cgi?article= 1190\&context=ersc, last access: 25 November 2018.

Hatchett, B. J., Daudert, B., Garner, C. B., Oakley, N. S., Putnam, A. E., and White, A. B.: Winter Snow Level Rise in the Northern Sierra Nevada from 2008 to 2017, Water, 9, 899, https://doi.org/10.3390/w9110899, 2017.

Huss, M., Bookhagen, B., Huggel, C., Jacobsen, D., Bradley, R. S., Clague, J. J., Vuille, M., Buytaert, W., Cayan, D. R., Greenwood, G., Mark, B. G., Milner, A. M., Weingartner, R., and Winder, M.: Toward mountains without permanent snow and ice, Earths Future, 5, 418-435, https://doi.org/10.1002/2016EF000514, 2017.

Keddy, P. A., Spavold, A. J., and Keddy, C. J.: Snowmobile impact on old field and marsh vegetation in Nova Scotia, Canada: An experimental study, Environ. Manage., 3, 409-415, https://doi.org/10.1007/BF01866580, 1979.

Margulis, S., Girotto, M., Cortés, G., and Durand, M.: A particle batch smoother approach to snow water equivalent estimation, J. Hydrometeorol., 16, 1752-1772, https://doi.org/10.1175/JHMD-14-0177.1, 2015.

Margulis, S. A., Cortés, G., Girotto, M., and Durand, M.: A Landsat-Era Sierra Nevada Snow Reanalysis (1985-2015), J. Hydrometeorol., 17, 1203-1221, https://doi.org/10.1175/JHMD-15-0177.1, 2016.

McBoyle, G., Scott, D., and Jones, B.: Climate change and the future of snowmobiling in non-mountainous regions of Canada, Manag. Leisur., 12, 237-250, https://doi.org/10.1080/13606710701546868, 2007.

McCabe, G. J., Wolock, D. M., and Valentin, M.: Warming is driving decreases in snow fractions while runoff efficiency remains mostly unchanged in snow-covered areas of the western United States, J. Hydrometeorol., 19, 803-814, https://doi.org/10.1175/JHM-D-17-0227.1, 2018. 
Mote, P. W., Li, S., Lettenmaier, D. P., Xiao, M., and Engel, R.: Dramatic declines in snowpack in the western US, npj Clim. Atmos. Sci., 1, 2, https://doi.org/10.1038/s41612-018-0012-1, 2018.

Oyler, J. W., Dobrowski, S. Z., Ballantyne, A. P., Klene, A. E., and Running, S. W.: Artificial amplification of warming trends across the mountains of the western United States, Geophys. Res. Lett., 42, 153-161, https://doi.org/10.1002/2014GL062803, 2015.

Patterson, G. G.: Trends in accumulation and melt of seasonal snow in and near Rocky Mountain National Park, Colorado, USA, with emphasis on monthly variations, PhD Dissertation, Colorado State University, available at: http://sites.warnercnr. colostate.edu/srf/wp-content/uploads/sites/74/2017/09/CSU_ Earth_Sciences_PhD_dissertation_F2016-Glenn_Patterson.pdf, (last access: 8 July 2018), 2016.

Perry, E., Manning, R., Xiao, X., Valliere, W., and Reigner, N.: Social climate change: The advancing extirpation of snowmobilers in Vermont, J. Park Rec. Admin., 36, 31-51, https://doi.org/10.18666/JPRA-2018-V36-I2-8307, 2018.

Polade, S. D., Pierce, D. W., Cayan, D. R., Gershunov, A., and Dettinger, M. D.: The key role of dry days in changing regional climate and precipitation regimes, Sci. Rep., 4, 4364, https://doi.org/10.1038/srep04364, 2014.

Rajagopal, S. and Harpold, A. A.: Testing and improving temperature thresholds for snow and rain prediction in the Western United States, J. Am. Water Resour. Assoc., 52, 1142-1154, https://doi.org/10.1111/1752-1688.12443, 2016.

Scott, D., Dawson, J., and Jones, B. Climate change vulnerability of the U.S. Northeast winter recreation-tourism sector, Mitig. Adapt. Strat. Glob. Chang., 13, 577-596, https://doi.org/10.1007/s11027-007-9136-z, 2008.

Steiger, R., Scott, D., Abegg, B., Pons, M., and Aall, C.: A critical review of climate change risk for ski tourism, Curr. Issues Tour., 2, 1-37, https://doi.org/10.1080/13683500.2017.1410110, 2017.

Sturm, M., Taras, B., Liston, G. E., Derksen, C., Jonas, T., and Lea, J.: Estimating Snow Water Equivalent Using Snow Depth Data and Climate Classes, J. Hydrometeorol., 11, 1380-1394, https://doi.org/10.1175/2010JHM1202.1, 2010.
Swain, D. L., Langenbrunner, B., Neelin, J. D., and Hall, A.: Increasing precipitation volatility in twenty-firstcentury California, Nat. Clim. Change, 8, 427-433, https://doi.org/10.1038/s41558-018-0140-y, 2018.

Tercek, M. and Rodman, A.: Forecasts of 21st Century Snowpack and Implications for Snowmobile and Snowcoach Use in Yellowstone National Park, PLoS ONE, 11, e0159218, https://doi.org/10.1371/journal.pone.0159218, 2016.

United States Census Bureau: County Business Patterns 2013, available at: http://www.headwaterseconomics.org/tools/ economic-profile-system (last access: 20 May 2018), 2016.

United States Department of Agriculture Natural Resources Conservation Service: SNOTEL Historic Data, available at: https: //wcc.sc.egov.usda.gov/nwcc/tabget, last access: 1 June 2018.

United States Forest Service (USFS): Modifications Made to Medicine Bow National Forest Winter Travel Special Order - Release date 15 November 2013, Medicine Bow National Forest, available at: https://www.fs.usda.gov/detail/mbr/ news-events/?cid=STELPRDB5440798 (last access: 10 June 2018), 2013.

Walton, D. B., Hall, A., Berg, N., Schwartz, M., and Sun, F.: Incorporating Snow Albedo Feedback into Downscaled Temperature and Snow Cover Projections for California's Sierra Nevada, J. Climate, 30, 1417-1438, https://doi.org/10.1175/JCLI-D-160168.1, 2017.

Wobus, C., Small, E. E., Hosterman, H., Mills, D., Stein, J., Rissing, M., Jones, R., Duckworth, M., Hall, R., Kolian, R., Creason, J., and Martinich, J.: Projected climate change impacts on skiing and snowmobiling: A case study of the United States, Global Environ. Chang., 45, 1-14, https://doi.org/10.1016/j.gloenvcha.2017.04.006, 2017. 